\title{
Observations of the altitude of the volcanic plume during the eruption of Eyjafjallajökull, April-May 2010
}

\author{
P. Arason, G. N. Petersen, and H. Bjornsson \\ Icelandic Meteorological Office, Reykjavik, Iceland \\ Received: 12 May 2011 - Published in Earth Syst. Sci. Data Discuss.: 23 May 2011 \\ Revised: 11 August 2011 - Accepted: 31 August 2011 - Published: 5 September 2011
}

\begin{abstract}
The eruption of Eyjafjallajökull volcano in 2010 lasted for 39 days, 14 April-23 May. The eruption had two explosive phases separated by a phase with lava formation and reduced explosive activity. The height of the plume was monitored every 5 min with a C-band weather radar located in Keflavík International Airport, $155 \mathrm{~km}$ distance from the volcano. Furthermore, several web cameras were mounted with a view of the volcano, and their images saved every five seconds. Time series of the plume-top altitude were constructed from the radar observations and images from a web camera located in the village Hvolsvöllur at $34 \mathrm{~km}$ distance from the volcano. This paper presents the independent radar and web camera time series and performs cross validation. The results show good agreement between the time series for the range when both series are available. However, while the radar altitudes are semi-discrete the data availability was much higher than for the web camera, indicating how essential weather radars are as eruption plume monitoring devices. The echo top radar series of the altitude of the volcanic plume are publicly available from the Pangaea Data Publisher (http://dx.doi.org/10.1594/PANGAEA.760690).
\end{abstract}

\section{Introduction}

An explosive volcanic eruption started in the summit of the ice-capped Eyjafjallajökull volcano in southern Iceland on 14 April 2010. The volcanic plume from the eruption was monitored using a C-band weather radar located $155 \mathrm{~km}$ from the volcano, and by web cameras situated near the volcano, as well as by visual observations from the ground and air.

The summit eruption had two explosive phases, 1418 April and 3-20 May. During these phases the eruption plume reached an altitude ranging from 5 to $10 \mathrm{~km}$. Between the two explosive phases the volcanic plume was much lower, with altitude ranging from below radar detection level to about $5 \mathrm{~km}$. A short meteorological overview of the eruption was presented by Petersen (2010).

The eruption of Eyjafjallajökull caused major disruption of air traffic in northern and western Europe as upper level winds advected fine-grained silicic ash rapidly southeastward and later southward. During and after the eruption numerous scientific questions have surfaced, regarding the specifics of

Correspondence to: P. Arason (arason@vedur.is) how high the volcanic plume rose, and how far the ash cloud was dispersed.

The purpose of this article is to describe the time series of the altitude of the volcanic plume as measured by the weather radar and the web camera that had the best view of the eruption plume. These are unique time series with a time resolution of $5 \mathrm{~min}$ covering the duration of the eruption from 14 April to 23 May 2010.

In the following section we give detailed description of the weather radar and its placement, specifications and limitations. Section 3 contains a similar, albeit shorter, discussion for the web camera. In Sect. 4 we present the two data series and cross validate them in Sect. 5. Finally there are some concluding remarks in Sect. 6.

\section{The weather radar at Keflavík airport: specifications and limitations}

\subsection{Specifications}

The weather radar at Keflavík International Airport in southwest Iceland was the only operational weather radar in Iceland during the eruption. It is an Ericsson C-band radar, in a fixed position, about $3 \mathrm{~km}$ north of the airport and 
Table 1. Specifications of the weather radar system in Keflavík, southwest Iceland.

\begin{tabular}{ll}
\hline Type & C-band Ericsson radar system $(5.6 \mathrm{GHz})$ \\
Operational since & January 1991 \\
Doppler since & April 2010 \\
Location & $64^{\circ} 01^{\prime} 35^{\prime \prime} \mathrm{N}, 22^{\circ} 38^{\prime} 09^{\prime \prime} \mathrm{W}$ \\
Height of antenna & $47 \mathrm{~m}$ above sea level \\
Peak transmitted power & $245.2 \mathrm{~kW}$ \\
Pulse duration & $2.15 \mu \mathrm{s}$ \\
Wavelength & $5.4 \mathrm{~cm}$ \\
Pulse repetition rate & $250 \pm 2 \mathrm{~Hz}$ \\
Maximum range & $480 \mathrm{~km}$ \\
Actual gain of antenna & $44.9 \mathrm{dBZ}$ \\
Duration of a reflectivity scan & $10 \mathrm{~s} \mathrm{per} \mathrm{elevation} \mathrm{angle}$ \\
Duration of a doppler scan & $30 \mathrm{~s} \mathrm{per} \mathrm{elevation} \mathrm{angle}$ \\
Duration of a beam raising & $1-2 \mathrm{~s} \mathrm{for} \mathrm{the} \mathrm{lowest} \mathrm{elevation} \mathrm{angles}$ \\
Half-power beam width & $0.9^{\circ}$ \\
Elevation angles reflectivity scans & $0.5^{\circ}, 0.9^{\circ}, 1.3^{\circ}, 2.4^{\circ}, 3.5^{\circ}, 4.5^{\circ}, 6.0^{\circ}, 8.0^{\circ}, 10.0^{\circ}, 15.0^{\circ}, 25.0^{\circ}$ and $40.0^{\circ}$ \\
Altitude of 4 lowest level beam midpoints over the volcano & $2.8,3.9,4.9$ and $7.9 \mathrm{~km}$ a.s. 1. \\
Elevation angles doppler scans & $0.5^{\circ}, 1.3^{\circ}, 2.4^{\circ}, 5.0^{\circ}, 7.0^{\circ}, 10.0^{\circ}, 15.0^{\circ}, 20.0^{\circ}$ and $30.0^{\circ}$ \\
Reflectivity threshold (echo top) & $-20 \mathrm{dBZ}$ \\
Data managing software & Rainbow ${ }^{\circledR} 5$ \\
\hline
\end{tabular}

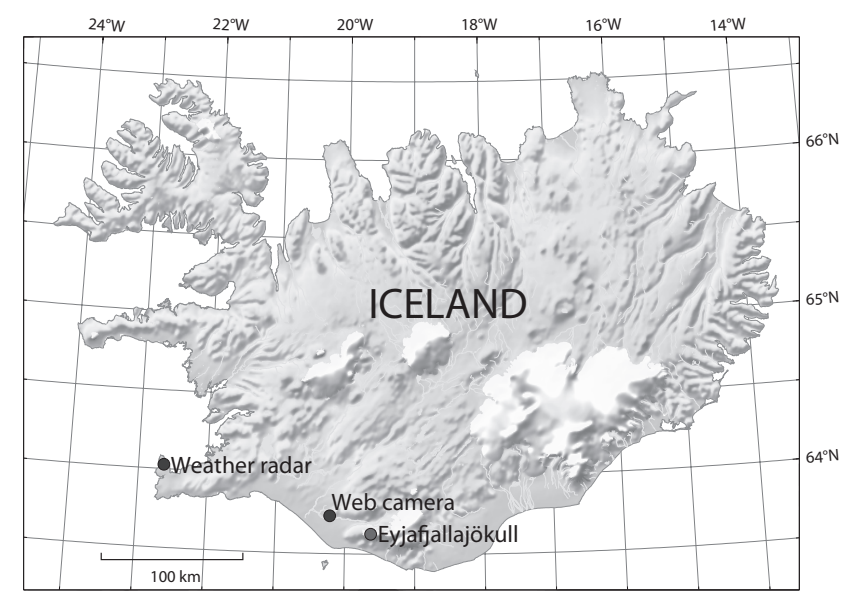

Figure 1. A map of Iceland and the location of the weather radar at Keflavík airport, the web camera in the village of Hvolsvöllur and the Eyjafjallajökull volcano in South Iceland. The radar is about $155 \mathrm{~km}$ from the volcano and in between there is a mountain range that obstructs the view of the plume when below $2.9 \mathrm{~km}$ a.s.l.

$155 \mathrm{~km}$ from the Eyjafjallajökull volcano (Fig. 1). The radar monitors precipitation and precipitating clouds within a maximum range of $480 \mathrm{~km}$ from its location. The radar was upgraded to a doppler radar in March 2010 and the weather data management software from SELEX-Gematronic was updated during April 2010 from Rainbow ${ }^{\circledR} 3$ to Rainbow ${ }^{\circledR} 5$. Due to these changes operational doppler scans began during the eruption, towards the end of April. The description and specifications of the radar system are given in Table 1 .
The radar was installed in 1991, and prior to the Eyjafjallajökull eruption it had been successfully used for monitoring five volcanic eruptions in Iceland: Hekla in 1991, only a few days after the radar became operational (Larsen et al., 1991), Gjálp in 1996, Grímsvötn in 1998, Hekla in 2000 (Lacasse et al., 2004) and Grímsvötn in 2004 (Vogfjörd et al., 2005; Oddson, 2007).

The current scanning strategy for normal weather monitoring is to make $240 \mathrm{~km}$ reflectivity scans for 12 elevations (radar inclination angles) every $15 \mathrm{~min}$ (at 00, 15, 30 and $45 \mathrm{~min}$ past the hour) as well as $120 \mathrm{~km}$ doppler scans for nine elevations every $15 \mathrm{~min}$ (at 7,22, 37 and $52 \mathrm{~min}$ past the hour). In case of a volcanic eruption within a radius of $240 \mathrm{~km}$ from the radar, the strategy is to make $240 \mathrm{~km}$ reflectivity scans every five minutes (except at 5 and $35 \mathrm{~min}$ past the hour when $120 \mathrm{~km}$ doppler scans are made). The radar clock is automatically adjusted to a time server clock. Each reflectivity scan takes $2.5 \mathrm{~min}$. The actual scan of the lowest elevation angle starts about $10 \mathrm{~s}$ after the registered time. Each revolution of the radar antenna takes $10 \mathrm{~s}$ and the raising between the lowest elevation levels takes $1-2 \mathrm{~s}$. This means that the plume-top during the Eyjafjallajökull eruption was observed by the radar about 10-50 s after the registered time.

Volume reflectivity data and images are archived at the Icelandic Meteorological Office. These include images of maximum reflectivity (dBZ) over all available altitudes, plain radar sweeps of reflectivity (dBZ) increasing in altitude with distance from the radar, pseudo constant altitude reflectivity (Pseudo CAPPI, dBZ) at $2 \mathrm{~km}$ a.s.l. and the maximum altitude (km a.s.l.) of reflectivity. The images of the maximum altitude of reflectivity, or echo top images, show the highest 
vertical level from which detectable radar echoes are measured.

\subsection{Detection limits and uncertainties}

The scanned images are obtained as the radar beam circles from an initial angle of $0.5^{\circ}$, increasing the elevation angle at the end of each circle to a maximum angle of $40^{\circ}$ for reflectivity scans. For a list of elevation angles applied see Table 1. The cloud altitude detected by the weather radar for standard atmospheric refraction can be calculated by the elevation angle of the radar beam, the range from the radar to the point of interest, and the curvature of the earth:

$H=\sqrt{r^{2}+(k R)^{2}+2 r k R \sin (\phi)}-k R+H_{0}$

where $H$ is the altitude of the radar beam a.s.l. $(\mathrm{km}), H_{0}$ is the altitude a.s.l. $(\mathrm{km})$ of the radar antenna, $r$ is the range $(\mathrm{km}), \phi$ is the elevation angle (degrees), $R$ is Earth's radius, $R=6371 \mathrm{~km}$, and $k=4 / 3$ for standard atmospheric conditions (Rhinehart, 1991).

Furthermore, the width of the beam is a function of the range, and the half-power beam width, $\theta$ (degrees):

$W=r \tan \theta$

When this is applied to the Keflavík radar, in regards to an eruption in Eyjafjallajökull, the lowest detectable cloud height above Eyjafjallajökull would be $2.7 \mathrm{~km}$ a.s.l. and the beam width $2.4 \mathrm{~km}$. However, the lowest part of the beam does not reach Eyjafjallajökull. It is blocked by a mountain ridge, Brennisteinsfjöll (600 m a.s.1.), at a distance of $43 \mathrm{~km}$ from the radar. As a consequence the lowest angle of the beam reaching Eyjafjallajökull is $0.59^{\circ}$ or $2.9 \mathrm{~km}$ in altitude. In fact, partial beam blockage of the lowest elevation angle $\left(0.5^{\circ}\right)$ in the direction of Eyjafjallajökull has been estimated to be at least $60 \%$, using a $1 \mathrm{~km}$ digital elevation model (Crochet, 2009). This partial beam blockage means that the radar software assumes the beam reflection to be lower than it actually is, which can lead to a low bias in plume height estimates when the plume is only seen by the lowest beam.

An echo top algorithm is applied on the polar volume reflectivity raw data. For each horizontal pixel a vertical column of available data, on elevation planes, is derived for the height interval specified. The height interval for the Keflavík radar, at current configuration, is 0 to $12 \mathrm{~km}$ altitude. This configuration can easily be modified when necessary but is usually preferred for precipitation monitoring and was indeed suitable for the Eyjafjallajökull eruption. The echo top is defined as the highest altitude where the threshold reflectivity is exceeded, with the threshold reflectivity for the Keflavík radar being $-20 \mathrm{dBZ}$. An interpolation of the reflectivity value of the highest beam exceeding the threshold and the reflectivity value of the beam above are used to estimate the echo top altitude.

This means that the altitude given as echo top not only depends on the elevation angle and the range but also on

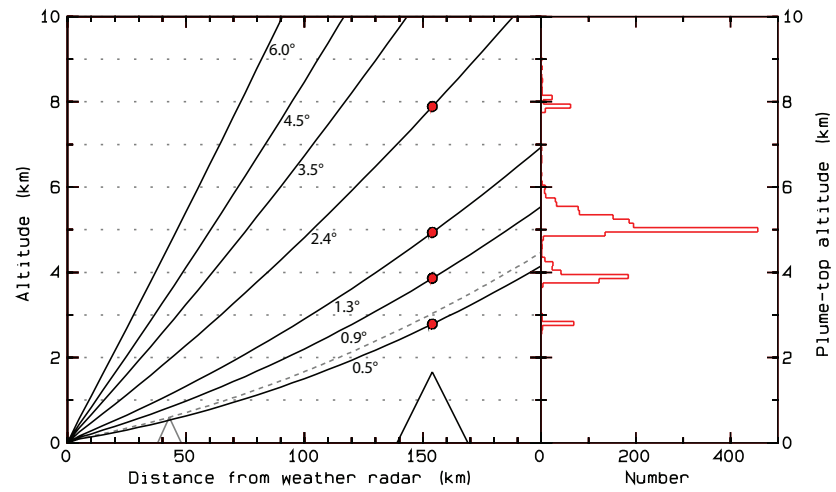

Figure 2. Left: A range-height diagram of the altitude (km a.s.l.) as a function of distance from the Keflavík radar $(\mathrm{km})$ for the lowest elevation angles $\left(0.5^{\circ}-6.0^{\circ}\right)$ of the scanning strategy during the eruption, calculated using Eq. (1). The location of Eyjafjallajökull is marked with a triangle and the lowest elevation angle of the obstacles due to Brennisteinsfjöll mountain range with a dashed line. Right: A histogram of plume-top altitudes estimated by the radar.

the observed reflectivity values. Furthermore, the larger the range, the larger the interval between the elevation angle levels resulting in larger uncertainties in the echo top height estimates. Figure 2 shows the seven lowest elevation angles of the current scanning strategy and their height above sea level for a distance of up to $200 \mathrm{~km}$. The half-power beam width of $0.9^{\circ}$ results in an overlapping of the beams for the three lowest elevation angles, $0.5-1.3^{\circ}$. When the radar only detects the plume with the lowest beam $\left(0.5^{\circ}\right)$, the height is assumed to be at the centre of the beam, at $2.7 \mathrm{~km}$ altitude, even though the lowest possible detected plume height above Eyjafjallajökull is $2.9 \mathrm{~km}$. Figure 3 shows an example of an echo top image from the eruption period. Eyjafjallajökull is located at the southern coast of Iceland and here the volcanic plume altitude was observed at $8.1 \mathrm{~km}$. Most of the time the plume top was above the volcano, but in a few cases atmospheric conditions led to further rise of the plume downwind for tens of $\mathrm{km}$. For this study we chose to limit the data to the observed altitude of the plume above the volcano.

Figure 4 shows the availability of the echo top altitudes of the volcanic cloud for the duration of the eruption from 14 April to 23 May. In total the echo top heights were available $45 \%$ of the time. There are four reasons for nonavailability: (i) The altitude of the volcanic plume is too low to be detected by the radar ( $27 \%$ of the time), (ii) the volcanic plume is obscured by precipitating clouds $(11 \%)$, (iii) the radar scan is missing (7\%) and (iv) short range doppler scans for weather monitoring were made twice per hour following 29 April and did not reach the volcano $(10 \%)$. Note that the frequency of missing scans is higher than expected in routine monitoring due to increased strain on the operations. The figure also shows that during the best days the echo top altitudes were available over $80 \%$ of time but at worst there 


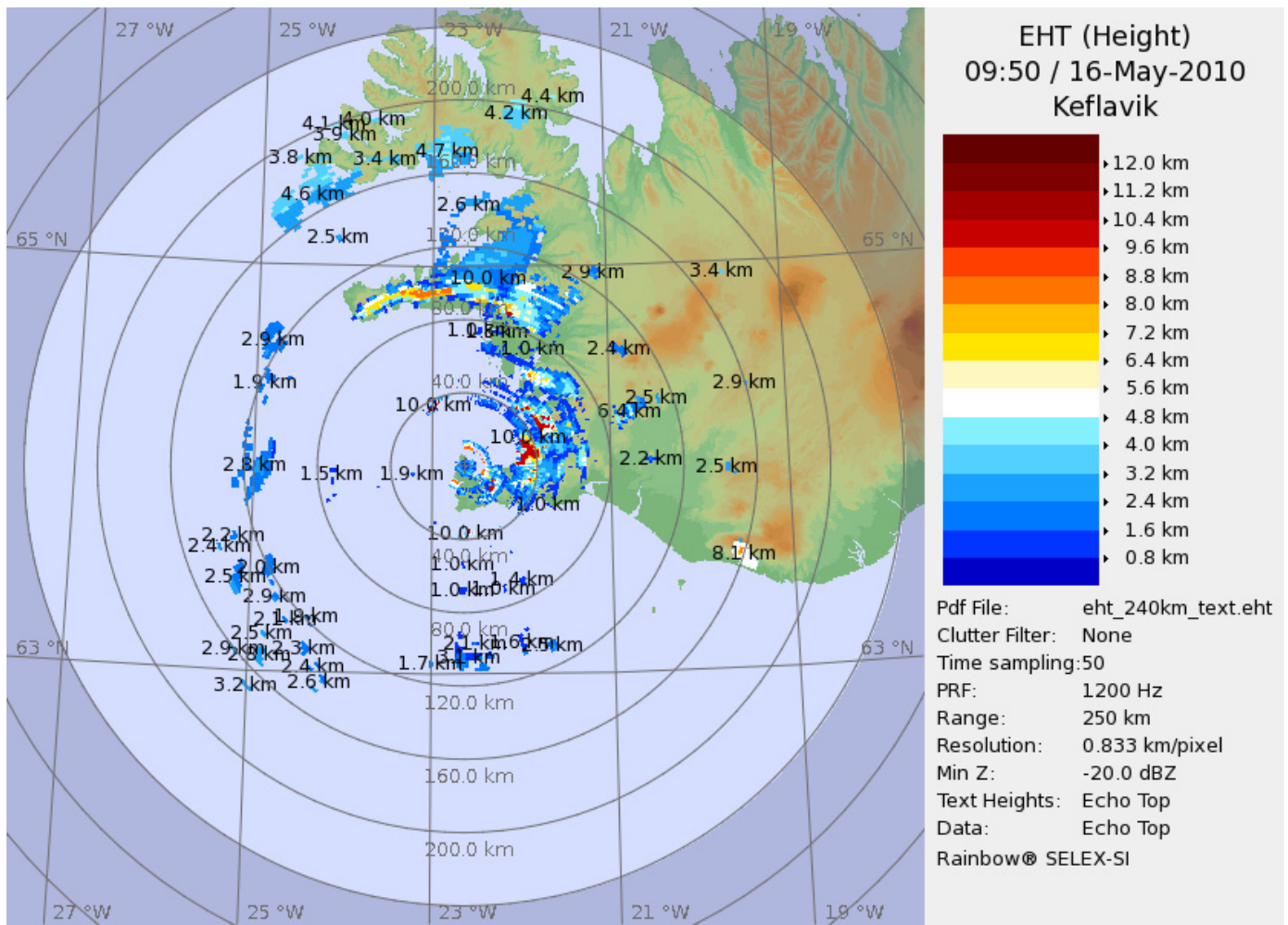

Figure 3. An echo top image of the weather radar scan at 09:50 UTC 16 May 2010.

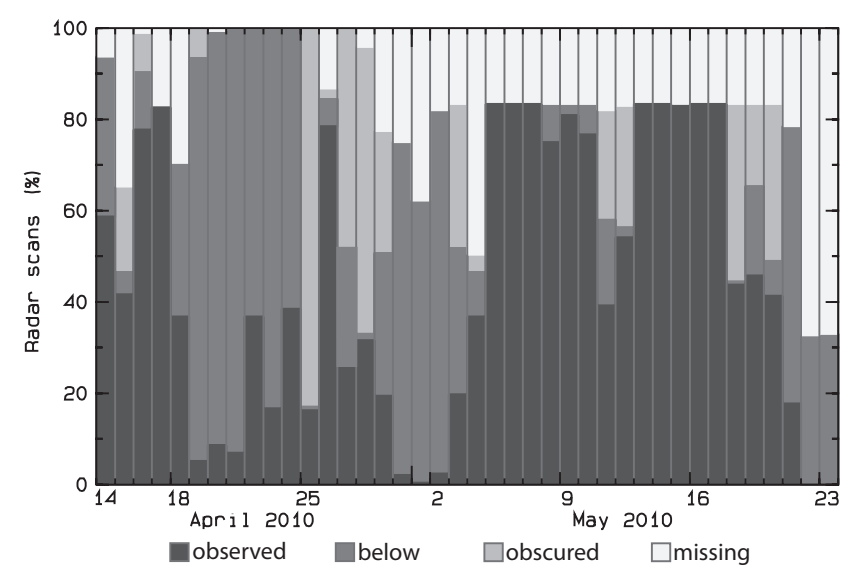

Figure 4. Availability of the 5-min radar data for each day of the eruption, 14 April to 23 May 2010. The figure shows the fraction of scans where (a) Echo top of the plume was observed by the radar (darkest shading), (b) plume was below the minimum detection height, (c) the plume was obscured by precipitating clouds and (d) the radar scans were missing (white). Note that after 29 April two $120 \mathrm{~km}$ doppler scans per hour replaced reflectivity scans leading to an increase in missing scans. was no radar detection, although other methods of monitoring confirmed a continued eruption. In all, there are 5139 distinct estimates of plume altitude for the duration of the eruption.

\section{The web camera at Hvolsvöllur: specifications and limitations}

Several web cameras were mounted with a view of the volcano by various commercial entities. Their main purpose was to give the general public an opportunity to follow the eruption in real time. However, the web cameras were also found to be of use for scientific monitoring of the eruption. The most useful camera for monitoring the plume was owned by the telecommunications company Míla, located in a mast in the village of Hvolsvöllur, $34 \mathrm{~km}$ from the volcano, with a clear view of the volcano and the sky above. The web camera images were saved every five seconds, with vertical resolution at the volcano of about 15 pixels per $100 \mathrm{~m}$. The vertical extent of the camera frame was limited to about $5.2 \mathrm{~km}$ a.s.l. or roughly $3.5 \mathrm{~km}$ above the summit of the volcano (Fig. 5). We have been able to verify that the registered time of the images is correct. 


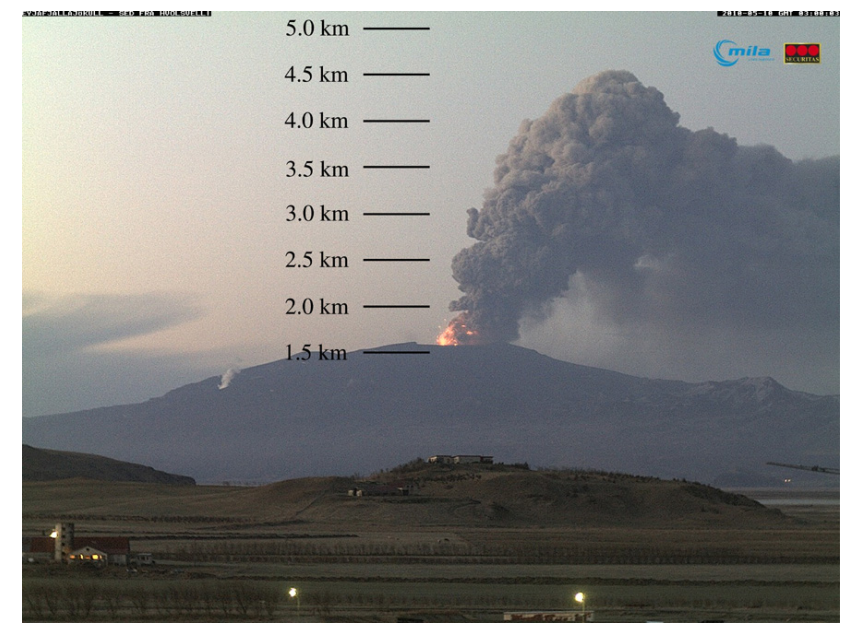

Figure 5. Web camera image acquired on 10 May at 03:00 UTC. The figure also shows the altitude levels above the volcano in km a.s.l.

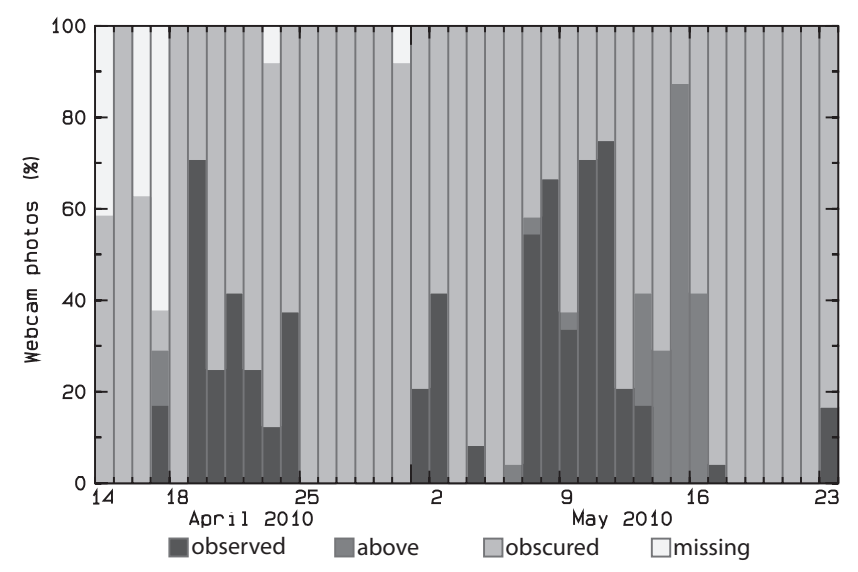

Figure 6. Availability of the hourly web camera data for each day of the eruption, 14 April to 23 May 2010. The figure shows the fraction of web camera photos where (a) the plume height was observed by the camera (darkest shading), (b) the plume was visible but extended above the image frame, (c) visibility was poor and the plume was obscured and (d) the images are missing.

From the web camera images a time series was constructed consisting of hourly plume altitude estimates. Figure 6 shows the availability of the hourly estimates. The camera afforded a clear view of the plume-top $17 \%$ of the time, and additional $5 \%$ of the images show the plume penetrating above the frame of the images. The view was obscured $74 \%$ of the time, and $4 \%$ of the images are missing. In total there are 158 hourly images where the plume-top was visible. In addition during the periods when the plume was visible the data set was extended to include altitude estimates at $5 \mathrm{~min}$ intervals. Thus the complete web camera data series contains 1821 altitude estimates.

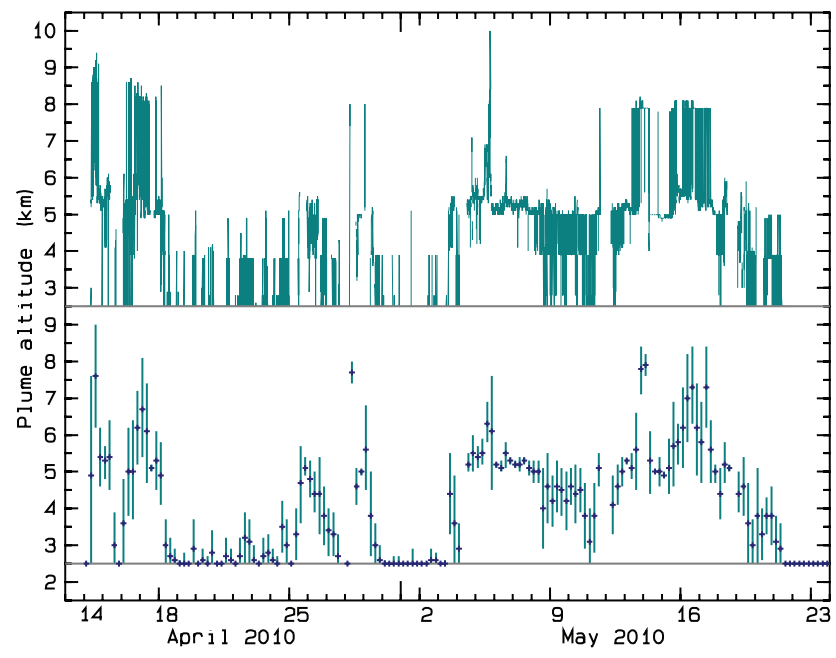

Figure 7. Upper panel: The 5-min time series of the echo top radar data of the eruption plume altitude (km a.s.l.). Lower panel: A 6-h average of the echo top height of the eruption plume (km a.s.l.). The bars represent one standard deviation.

In estimating the plume-top altitudes from the camera images we have assumed that the plume-top seen on the images is $34 \mathrm{~km}$ from the camera. During high winds this is obviously not true, and when the plume was blowing to the side, the images show the plume-top up to $5 \mathrm{~km}$ downwind of the summit. A movement $3.4 \mathrm{~km}$ away or towards the camera leads to $10 \%$ over- or underestimation of the altitude. Therefore, the uncertainty of the web camera plume-top altitudes should be regarded to be on the order of $10 \%$.

\section{The time series of plume-top altitudes during the Eyjafjallajökull eruption 2010}

A time series has been constructed from the radar detected echo tops. The upper panel in Fig. 7 shows the 5-min time series of all available echo top altitudes of the eruption plume. The eruption started at about 01:00 UTC on 14 April and the volcanic plume was first detected by the radar at 08:50 UTC. The last radar observation of the plume was at 10:20 UTC on 21 May. The time series shows that there were large variations in echo top height at any given time and semidiscrete jumps are apparent. The jumps are a consequence of the scanning strategy and increase with altitude as the vertical distance between the elevation angles increases (see also Fig. 2).

In order to get a better picture of the height variation of the plume, the lower panel in Fig. 7 shows the 6-h mean plume altitude along with standard deviations. The figure gives a clear picture of the large variations in the eruption strength. During the first few days the plume altitude varied mainly between 5 and $7 \mathrm{~km}$ followed by a period of weaker activity on 18-24 April with plume altitude of 3-4 km. After almost 
Table 2. Comparison of simultaneous measurements by radar and web camera. Separate lines show the radar scanning angle and height range classes as estimated by radar, while the columns show the range, average and standard deviation of web camera estimates made at the same time. The last column shows the number of height estimates used to calculate the average and standard deviation. All height values are in kilometers above sea level.

\begin{tabular}{cccccc}
\hline Radar scanning & Radar & \multicolumn{4}{c}{ Web camera } \\
\cline { 3 - 6 } elevation angle & height range & Range & mean & sd & N \\
\hline $0.5^{\circ}$ & $<3.5$ & $3.4-4.4$ & 3.95 & 0.24 & 48 \\
$0.9^{\circ}$ & $3.5-4.4$ & $2.3-5.1$ & 4.13 & 0.31 & 268 \\
$1.3^{\circ}$ & $4.5-5.4$ & $3.3-5.2$ & 4.65 & 0.33 & 520 \\
$2.4^{\circ}$ & $>5.4$ & $4.2-4.9$ & 4.57 & 0.29 & 10 \\
\hline
\end{tabular}

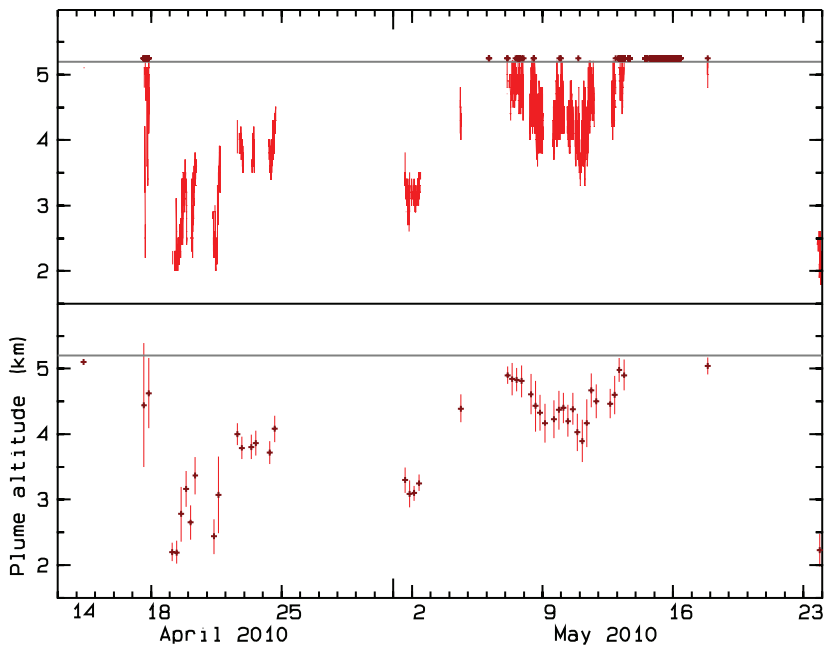

Figure 8. As in Fig. 7 but for the web camera data. The image frame ceiling at $5.2 \mathrm{~km}$ a.s.l. is shown.

a week of lower activity the eruption gained some strength on 25-29 April followed by another period with low plume height. On 3 May there was a sudden increase in the plume height with the initiation of a new phase of the eruption. During this last phase the plume rose to a maximum altitude of $7-8 \mathrm{~km}$ on 16 May, after which the plume decreased steadily.

In addition to the 5-min data set the data have been compiled into $1 \mathrm{~h}, 3 \mathrm{~h}, 6 \mathrm{~h}, 12 \mathrm{~h}$ and $24 \mathrm{~h}$ data sets. Each of these compiled data sets includes for each time step (i) information on the availability of radar scans, (ii) mean, minimum and maximum plume-top altitude, (iii) standard deviation of the plume-top altitude and (iv) median, lower and upper quartile of the plume-top altitude. When compiling these data sets the plume height is assumed to be $2.5 \mathrm{~km}$ a.s.l. when below the minimum detection level of the radar but other observations, e.g. web camera images, seismic measurements or pilot reports, confirm volcanic activity.

Figure 8 shows the time series of the plume-top altitudes constructed from the web camera data. Clearly, the reduced availability of the web camera data means that the time series is more sparse. However, the vertical resolution of the data is better up to the image ceiling at $5.2 \mathrm{~km}$ a.s.l.

\section{Cross-validation}

To validate the data, the radar echo top heights were compared to the web camera based time series from Hvolsvöllur. We are aware of the time difference of 10-50 s between the radar and web camera time series. An inspection of the web camera data shows that the 5-min height difference does not exceed $0.2 \mathrm{~km}$ two thirds of the time. Therefore, we expect the height difference in $10-50 \mathrm{~s}$ to be insignificant and refer to these measurements as simultaneous.

Contrasting the availability of the radar and web camera altitude estimates, we note that for the hourly values the radar gave information on the plume-top altitude $83 \%$ of the time, i.e. $50 \%$ are actual height estimates and for further $33 \%$ of the hourly values the echo top altitudes are below the detection height. The hourly web camera altitude estimates, on the other hand, were only available $22 \%$ of the time, with the plume top visible $17 \%$ of the time and an additional $5 \%$ of the estimates showed the plume extending above the image ceiling.

Figure 9 shows a comparison of all 5 min values for the radar (blue) and web camera (red). As noted above, the availability of the radar data was far better than that of the web camera data, but the vertical resolution in the web camera data is better for the height range that it covers. In many cases the radar echo top altitude was jumping between the 3.9 and $4.9 \mathrm{~km}$ levels (e.g. from 1-2 and 7-13 May), with small deviations due to differences in reflectivity (see Sect. 2.2), but the web camera time series show the plume height ranging in between these altitudes. On these days the discrete echo top levels nicely encapsulated the web camera altitudes.

To get a better understanding of the differences in height estimates between the web camera and radar it is instructive to consider each radar scanning angle separately (see Fig. 2). Table 2 shows a comparison of simultaneous measurements by radar and the web camera classified according to the radar scanning angle. 

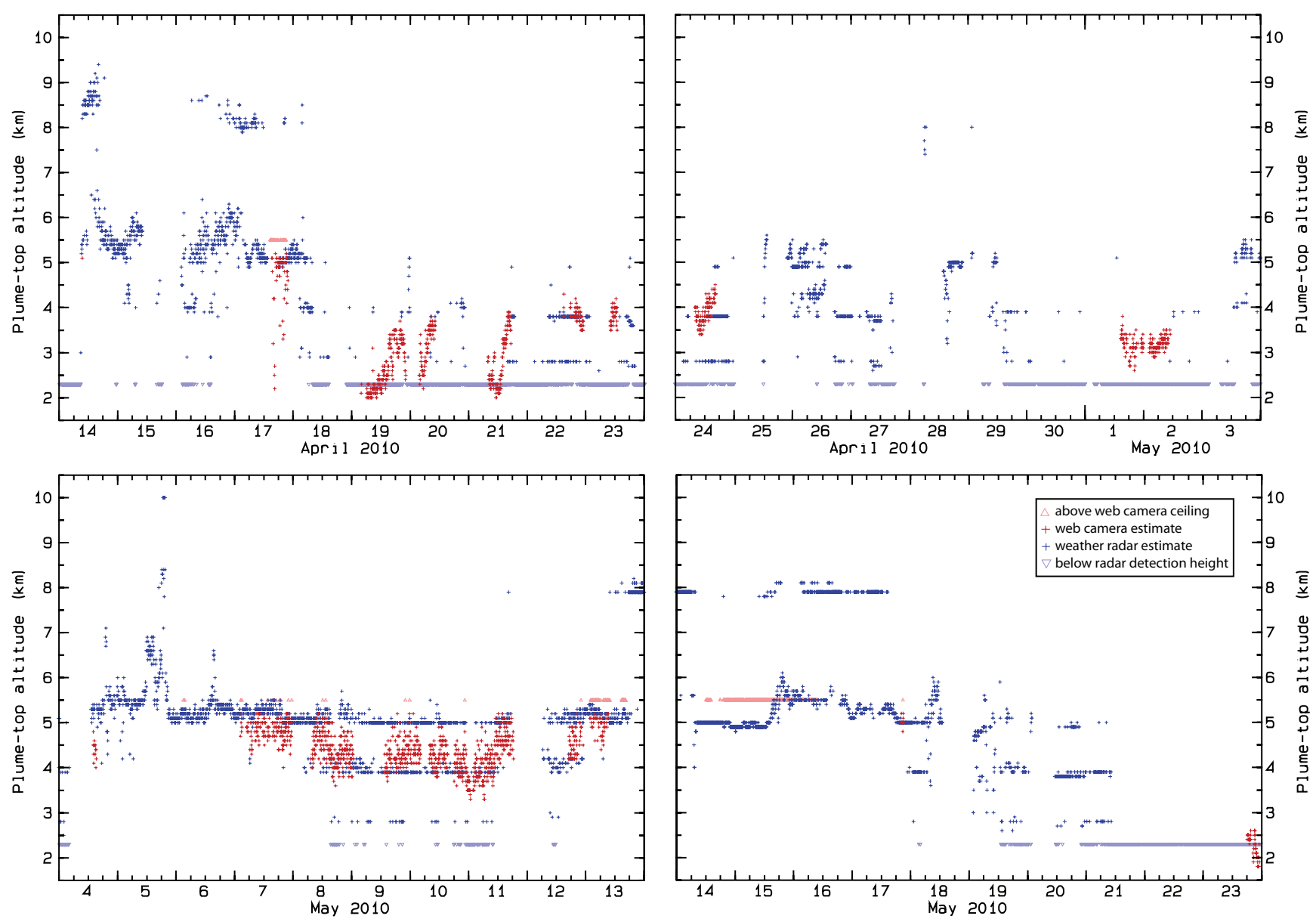

Figure 9. The time series of the 5-min values of the weather radar and web camera altitude estimates of the eruption plume (km a.s.1.). In some cases the plume was below the minimum radar detection height, and sometimes it extended above the web camera frame ceiling.

For the $0.5^{\circ}$ beam the radar altitudes are below $3.5 \mathrm{~km}$. However, the web camera altitudes range from 3.4 to $4.4 \mathrm{~km}$ with an average altitude of $3.95 \mathrm{~km}$. This difference is mainly due to the low bias caused by partial beam blockage of the $0.5^{\circ}$ radar scan, as discussed in Sect. 2.1.

For the $0.9^{\circ}$ beam the radar altitudes range from 3.5 to $4.4 \mathrm{~km}$. At the same time the average web camera height estimate was $4.13 \mathrm{~km}$ with a standard deviation of $0.3 \mathrm{~km}$. The average height of simultaneous radar estimates was only $0.2 \mathrm{~km}$ lower than than the web camera estimates, which is within one standard deviation. It should be noted that there were no cases of the radar estimating the plume height to be below $4.8 \mathrm{~km}$ and the web camera showing the plume extending above the image ceiling at $5.2 \mathrm{~km}$.

For the $1.3^{\circ}$ radar beam the table shows that while the radar values ranged from 4.5 to $5.4 \mathrm{~km}$ the web camera values were somewhat lower, ranging from 3.3 to $5.2 \mathrm{~km}$. The average altitude estimated by the web camera, $4.65 \mathrm{~km}$, is $460 \mathrm{~m}$ below the average of radar estimates at the same time. For this radar beam there were 299 cases when a radar alti- tude estimate was obtained while the web camera showed the plume penetrating above the image frame. These instances are therefore not included in the comparison above. If we assign some value over $5.2 \mathrm{~km}$ to the web camera data when the plume is clearly seen to penetrate above the frame, the difference between the radar and web camera decreases drastically, it becomes $200 \mathrm{~m}$ if we use $5.3 \mathrm{~km}$.

Finally, there are 10 cases where the radar estimates are above $5.4 \mathrm{~km}$ and the camera still shows the plume-top altitude to lie below $5.2 \mathrm{~km}$. However, there were 162 cases when the plume was clearly above the image frame ceiling while the radar gave a value above $5.4 \mathrm{~km}$. The mean of the 10 cases is therefore strongly biased. Further examination of the data shows that there were 461 cases where the plume height exceeded the web camera frame (i.e. was greater than $5.2 \mathrm{~km}$ ) and simultaneous height estimates from the radar are available. For these cases, the range of plumetop altitudes estimated by radar was $4.8-8.2 \mathrm{~km}$ with an average of $5.55 \mathrm{~km}$ and standard deviation of $1.0 \mathrm{~km}$. In this regard, it should be noted that there were no instances where 


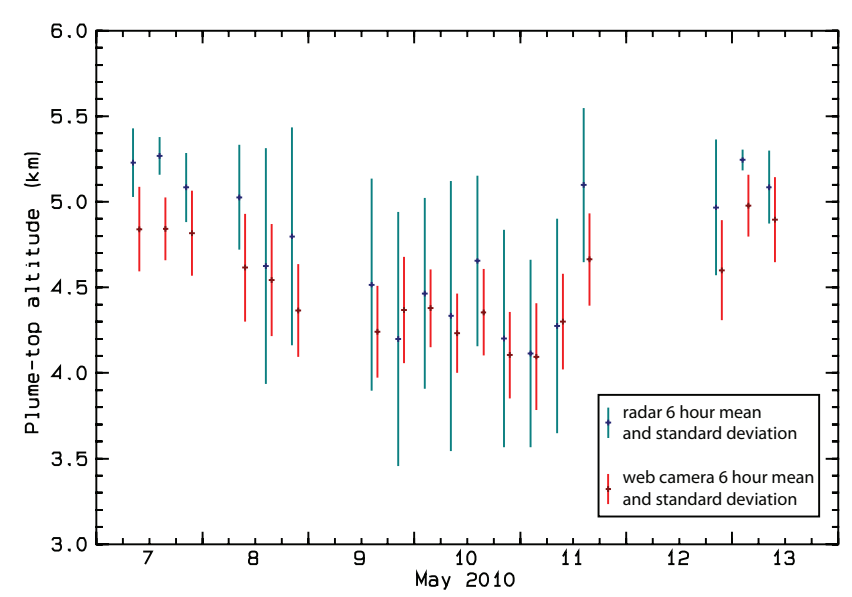

Figure 10. A comparison of altitude estimates from synchronous radar and web camera data, 7-13 May. The graph excludes cases when there were fewer than 10 synchronous observations during $6 \mathrm{~h}$.

the web camera showed the plume rising above the image frame while the radar placed the plume top within the two lowest beams $\left(0.5^{\circ}\right.$ or $\left.0.9^{\circ}\right)$.

Figure 7 clearly shows the discrete levels that arise in the 5 min data due to the different scanning angles. However, the figure also shows that this discreteness is not apparent in the 6-hourly averages. As was noted in the discussion of Fig. 9 during the period 7-13 May the radar heights alternated from 3.9 to $4.9 \mathrm{~km}$ while the web camera ranged in between. Figure 10 shows a comparison of 6-hourly averages of simultaneous plume-top altitude estimates by the radar and web camera during this period. Six hour intervals where fewer than 10 simultaneous altitude estimates exist are omitted. The agreement between the two different estimates is excellent and is a good argument for the validity of the radar height estimates, with the caveat that jumps between discrete radar levels will occur for $5 \mathrm{~min}$ data.

To summarise, the radar and the web camera height estimates compare fairly well. For the radar the biggest issue with regard to uncertainty are the discrete scanning angles and the resulting groups of echo top height levels. However, within the two levels where both the radar and web camera estimates are not seriously affected by either radar beam blockage or by the image frame ceiling, the difference between simultaneous radar and web camera height estimates is within the $10 \%$ uncertainty previously estimated for the web camera altitudes. For 6-hourly averages the influence of the discrete levels are much reduced and the agreement between the two data sets is excellent.

\section{Conclusions}

The eruption of Eyjafjallajökull caused major disruption of air traffic in northern and western Europe as upper level winds advected fine-grained silicic ash rapidly southeastward and later southward. During and after the eruption numerous scientific questions regarding medium-sized explosive eruptions have surfaced. This paper presents data that will be used to answer some of those questions, especially questions relating to the dispersion of the ash and volcanic aerosols, methods for tracking volcanic clouds and the interaction between the eruption plume and the atmosphere (see e.g. Carn et al., 2008; Tupper et al., 2009; Graf et al., 1999; Bursik, 2001; Prata, 2009).

The paper has described two independent time series of the altitude of the volcanic plume of the Eyjafjallajökull eruption April-May 2010 as observed with a weather radar located $155 \mathrm{~km}$ from the volcano and a web camera located $34 \mathrm{~km}$ from the volcano. The radar and camera observations were cross validated and we have discussed the inaccuracies in the data. Although both time series contain vital information about the eruption plume altitude and variations in time, the availability data shows that for monitoring purposes the radar was extremely useful. With regards to plume height the radar yielded valuable information about $80 \%$ of the time, whereas the web camera was only useful about $20 \%$ of the time. The results show that despite inaccuracies in radar data, due to discrete scanning levels, weather radars are very useful devices for monitoring volcanic plumes.

Acknowledgements. We would like to thank Árni Sigurðsson, Bolli Pálmason, Geirfinnur Smári Sigurðarson, Philippe Crochet, Sibylle von Löwis, Sigrún Karlsdóttir and Steinunn S. Jakobsdóttir for valuable discussions and assistance. Míla ehf. kindly supplied the web camera photographs for validation of the radar altitudes. Comments and suggestions of Christian Lacasse and Larry Mastin have improved the paper.

Edited by: M. E. Contadakis

\section{References}

Bursik, M.: Effect of wind on the rise height of volcanic plumes, Geophys. Res. Lett., 28, 3621-3624, 2001.

Carn, S. A., Prata, A. J., and Karlsdottir, S.: Circumpolar transport of a volcanic cloud from Hekla (Iceland), J. Geophys. Res., 113, D14311, doi:10.1029/2008JD009878, 2008.

Crochet, P.: Enhancing radar estimates of precipitation over complex terrain using information derived from an orographic precipitation model, J. Hydrol., 377, 417-433, doi:10.1016/j.jhydrol.2009.08.038, 2009.

Graf, H.-F., Herzog, M., Oberhuber, J. M., and Textor, C.: The effect of environmental conditions on volcanic plume rise, J. Geophys. Res., 104, 24309-24320, 1999.

Lacasse, C., Karlsdóttir, S., Larsen, G., Soosalu, H., Rose, W. I., and Ernst, G. G. J.: Weather radar observations of the Hekla 2000 eruption cloud, Iceland, Bull. Volcanol., 66, 457-473, 2004. 
Larsen, G., Vilmundardóttir, E., and Porkelsson, B.: Heklugosið 1991: Gjóskufallið og gjóskulagið frá fyrsta degi gossins (The Hekla eruption of 1991 - The tephra fall), Náttúrufræðingurinn, 61, 159-176, 1991.

Oddson, B.: The Grímsvötn eruption in 2004: Dispersal and total mass of tephra and comparison with plume transport models, Master's thesis, University of Iceland, 2007.

Petersen, G. N.: A short meteorological overview of the Eyjafjallajökull eruption 14 April-23 May 2010, Weather, 65, 203-207, doi:10.1002/wea.634, 2010.

Prata, A. J.: Satellite detection of hazardous volcanic clouds and the risk to global air traffic, Nat. Hazards, 51, 303-304, doi:10.1007/s11069-008-9273-z, 2009.
Rhinehart, R. E.: Radar for Meteorologists, University of North Dakota, Grand Forks, North Dakota, 1991.

Tupper, A., Textor, C., Herzog, M., Graf, H.-F., and Richards, M. S.: Tall clouds from small eruptions: the sensitivity of eruption height and fine ash content to tropospheric instability, Nat. Hazards, 51, 375-401, doi:10.1007/s11069-009-9433-9, 2009.

Vogfjörd, K. S., Jakobsdóttir, S. S., Gudmundsson, G. B., Roberts, M. J., Ágústsson, K., Arason, P., Geirsson, H., Karlsdóttir, S., Hjaltadóttir, S., Ólafsdóttir, U., Thorbjarnardóttir, B., Skaftadóttir, T., Sturkell, E., Jónasdóttir, E. B., Hafsteinsson, G., Sveinbjörnsson, H., Stefánsson, R., and Jónsson, T. V.: Forecasting and monitoring a subglacial eruption in Iceland, EOS Trans. AGU, 86, 245-248, doi:10.1029/2005EO260001, 2005. 